
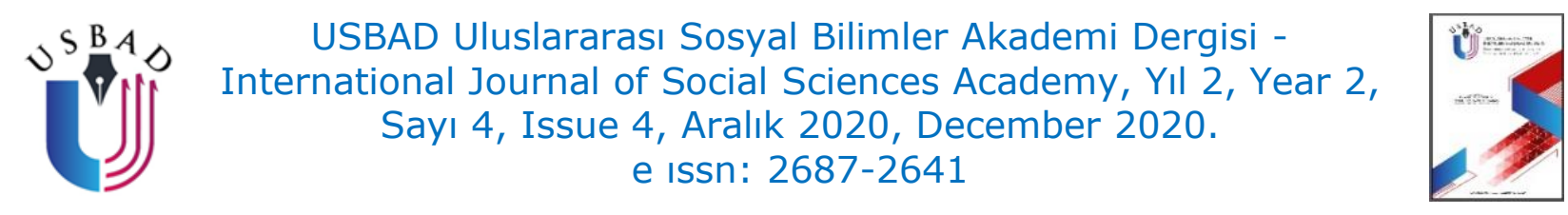

\title{
TÜRK DİLİNDE RETORİK SORU
}

\section{RHETORICAL QUESTION IN TURKISH LANGUAGE}

\author{
Nesrin GÜNAY \\ Doç. Dr., Türkçe Eğitimi Anabilim Dalı, Trakya Üniversitesi, Eğitim Fakültesi, \\ Edirne/Türkiye. \\ Assoc. Dr., Turkish Education Department, Trakya University, \\ Edirne/Turkey. \\ gunaynesrin@hotmail.com \\ ORCİD ID: 0000-0002-1255-7549
}

Makale bilgisi | Article Information

Doİ: 10.47994/usbad.707206

Makale Türü / Article Type: Araştırma Makalesi / Research Article

Geliş Tarihi / Date Received: 21.03.2020

Kabul Tarihi / Date Accepted: 16.07 .2020

Yayın Tarihi / Date Published: 20.12.2020

Yayın Sezonu / Pub Date Season: Aralık / December

Bu Makaleye Atıf İçin / To Cite This Article: Günay, N. (2020). Türk Dilinde Retorik Soru. USBAD Uluslararası Sosyal Bilimler Akademi Dergisi 2(4), 512-533.

İntihal: Bu makale intihal.net yazılımınca taranmıştır. İntihal tespit edilmemiştir.

Plagiarism: This article has been scanned by intihal.net. No plagiarism detected.

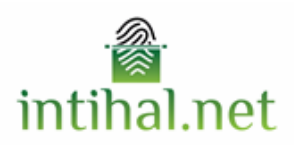

İletişim: Web: https://dergipark.org.tr/tr/pub/usbad mail: usbaddergi@gmail.com 
Öz: Retorik soru, muhatabı heyecanlandırma, ikna etme, hayrete düşürme; üstü kapalı söz söyleme söyleme gibi amaçlar için kullanılan soru cümlesidir. Retorik sorulara cevap beklenmez, sorunun muhatabı olmayabilir ya da sorulan sorunun cevabı zaten biliniyordur. Bu makalede, Köktürkçe, Uygur Türkçesi, Karahanlı Türkçesi dönemlerinden başlanarak, Eski Anadolu Türkçesi, Osmanlı Türkçesi, Türkiye Türkçesi dönemlerinde yazılmış bazı eserlerdeki retorik soru cümleleri anlamlarına göre sınıflandırılmıştır. Makale çerçevesini aşmamak için eser sayısı sınırlandııımış, her döneme ait en az bir eser taranmıştır. Taranan bütün retorik soru cümleleri makaleye dahil edilememiş, diğer örneklere göre daha ayırıcı nitelik taşıyan örnekler tercih edilmiştir. Derlenen bu cümleler metin içi ve metin dışı unsurlar esas alınarak incelenmiş ve anlamlarına göre sınıflandırılmıştır. Metin içi anlam belirlemede, anlam belirleyicilerin, kiplik ögelerinin cümlenin anlamına etkileri incelenmiştir. Metin dışı incelemede edim bilimi-sözcelem kuramlarından yararlanılmıştır. Şüphesiz, bu makale Türk Dilinde retorik soru cümlelerinin tamamını izah edecek kapsamda değildir; incelemeye esas aldığımız örnekler aracılığı ile, retorik soru cümlelerinin anlam özelliklerini belirleme ve sınıflandırmaya yönelik bir inceleme yapılmıştır. Sonuç olarak, bu eserlerde retorik soru cümlelerinin geniş bir anlam alanı olduğu görülmüştür. Bu bağlamda, Türkçe dil bilgisi incelemelerinde, anlamlarına göre cümle türleri konusunda retorik soru cümlelerinin anlam özelliklerine daha geniş yer verilmesinin yaralı olacağı öne sürülmüştür. Türk Dilinde retorik soru cümleleri üzerinde daha geniş izahat için, döneme ve esere bağlı monografik çalışmalara intiyaç vardır.

Anahtar Kelimeler: Retorik, Retorik Soru, Bağlam, Anlambilim, Edim Bilimi, Batı Türkçesi

Abstract: The rhetorical question is a question sentence used for purposes such as to excite, persuasion, astonishment, entertaining and implicit speech. The answer to the rhetorical questions is not expected, it may not be the addressee of the question or the answer to the question is already known. In this article, the rhetorical question phrases in some works written in the old Anatolian Turkish, Ottoman Turkish and Turkey Turkish periods, starting from the Köktürk, Uyghur Turkish and Karahanli Turkish periods, are classified according to their meaning. In order not to exceed the article frame, the number of works was limited and at least one work from each period was scanned. All rhetorical question phrases collected as data could not be included in the article and examples with more distinctive character were preferred over others. These compiled sentences were examined on the basis of in-text and non-text elements and classified according to their meaning. In determining meaning in text, the effects of meaning determiners and modality elements on the meaning of the sentence were studied. In non-text context analysis, pragmatics-speech theories have 
been used. There is no doubt that this article is not in the scope of explaining the full range of rhetorical question sentences in the Turkish language. As a result, rhetorical question sentences in these works have been seen to have a wide area of meaning.In this context, it has been suggested that the wider inclusion of rhetorical question sentences in the meaning characteristics of sentence types relative to their meaning would be beneficial in Turkish grammar studies. For more wide explanations on rhetorical question sentences in Turkish language, monographic studies related to period and work are needed.

Keywords: Rhetoric, Rhetorical Question, Semantics, Context, Pragmatics, West Turkish

\section{GİRİŞ}

Soru sormak, insanoğlunun bilme isteğinden doğmuştur ve insan olmanın temelini oluşturur; çünkü insan düşünen bir varlıktır, düşünce ise ancak soruyla doğar ve gelişir. İnsanoğlu, bir nokta öteye, bilgiye soruyla ulaşır. İnsan zihni, insanın doğasında var olan merak-soru-cevap üçgeni içinde dolaşır. Buradaki cevap, bilginin ve sonrasında gelecek yeni merak konusunun, dolayısıyla yeni sorunun da temsilcisidir (Çetin, 2008: 4). "Bir şeyi zihnen öğrenmek istemek, bir şeyin suretinin zihinde hâsıl olmasını talep etmek" olarak tanımlanan sormak fiili, Osmanlı Türkçesinde "istifham"ın, muhatabını karşılık vermeye yönelten inşa-yı talebî türü olarak tasnif edilmiştir. İstifhâm (استفهام) kelimesi " ف م م kök harflerinden oluşturulmuş istif'âl babında bir mastardır. "Fhm" kök harfleri; "bir şeyi bilmek, kalp ile sezmek, akıl etmek, anlamak" anlamlarına gelmektedir (Ateş, 2016: 124). Soru cümlesi, sormak fiilinin dile getirilmesini sağlayan araçlardan biridir; konuşucunun dinleyiciye bir şey sormak için kullandığı, anlamı soru olan, içinde bir soru ögesi bulunmasının yanı sıra kendine özgü bir vurgu ile belirlenen bir cümle türüdür. Ergin'e göre (1985) soru, fiillerde ve isimlerde soru ifade eden gramer kategorisidir. Bir fiil gösterdiği hareketin bir şahıs tarafından yapılıp yapılmadığını öğrenmek ve buna cevap istemek için soru şekline sokulur. Onun için fiillerde soru, kök veya gövdenin aldığı bir şekil değil, kök veya gövdeyi şahsa bağlayan fiil kiplerinin aldığı şekildir. Wilson ve Sperber (2004) soru cümlesini kip sistemi içinde değerlendirmiş ve kipin, cümlenin temel yapısal özelliklerini yöneten bir sistem olduğunu belirtmiştir.

Türkçede soru sormanın üç yolu vardır. Bunlardan birincisi cümlede "mı" biçimbirimini kullanmak, ikincisi "kim, nereye, ne 
zaman, nasıl" gibi soru kelimeleri kullanmak, üçüncüsü ise cümlenin ezgisini değiştirmektir (Korkmaz, 1992; Tâhir-ül Mevlevi, 1994; Vardar, 1998; Uzun, 2004; Bilgegil, 1989).

Türkçede soru sormak için her zaman soru cümlesi kullanılmadığı gibi her soru cümlesi de soru sormaz. Soru sorma eylemi her zaman bilgi edinme amacıyla kullanılmaz; başka eylemleri (davet, teklif, şikâyet, rica, istek vb.) ifade etmek için de yaygın şekilde kullanılır (Baytok, 2006: 79). Hem dil bilimi hem de edebiyat bilimi çerçevesinde incelenen bu soru türleri için, "gerçek olmayan soru", "sözde soru", "sahte soru", "cevap gerektirmeyen/beklenmeyen soru", "retorik soru", "sözbilimsel soru", "eğretilemeli soru" gibi farklı terimler kullanılmıştır. Makalede, bütün bu soru yapıları "retorik soru" terimi ile karşılanmıştır.

\section{RETORİK (KONUŞMA SANATI-SÖZ BİLİMİ)}

[İng. rhetoric], [Fr. rhétorique], [Alm. rhetorik], [Rusça ritorika], [Ar. balagha], [Lat.rhetorica], [Yun.rhêtorikê<rhêtôr], [Osm. Türkçesi belâgat]

Genel olarak, "dili ikna edecek biçimde kullanma sanatı" olarak tanımlanan retorik (rhetorike) terimi ilk kez Platon'un "Gorgias ya da Retorik Üstüne"diyalogunda "sanat" anlamında kullanılmıştır (Platon, 1999). Rhetos "söylenmiş şey, söz" kelimesine dayanır ve aslında bir kısaltmadır. Eski Yunanca rhetorikos "konuşmacıya ilişkin olan, yetenekli bir konuşmacı olmaya uygun olan" sıfatından türeyen rhetoriketekhne, "konuşmacının sanatı, konuşma sanatı" terimi ile karşılanır. "Techne"nin sanat, beceri, bilim gibi değişik anlamları bulunur. Romalılar "rheoteriketekhne" terimini kendi dillerinde Eski Yunanca rhetorike "söz söyleme sanatı, belagatli söz söyleme sanatı, söylev sanatı" sözcüğü ile ya da bunun Latinceleştirilmiş biçimi olan "rhetoricas" sözcüğü ile karşılamayı tercih etmişlerdir. Bu terim daha sonra diğer dünya dillerine girmiştir (Dürüşken, 2001: 2; Tepebaşlı, 2016: 15).

Aristoteles, retoriği "mevcut ikna edici araçları keşfetme becerisi" olarak tanımlar (Coşkun, 2014: 209). Retoriğin tematik ufku Platon tarafından çizilmiş/sınırlandııılmıştır. Platon'a göre retorik, gücü söze dayanan, konusu ve bütün eylem ve etkisi sözlerde ve yalnızca sözlerle gerçekleştirilen sanatlardan biridir. Retorik bilgi vermeyi değil, ikna etmeyi ve inandırmayı hedefler. Örnek olarak, Atina'daki tersaneler, surlar ve limanlar, sadece mimarlar, ustalar 
tarafından değil bu yapıların önemi hususunda fikir verenler ve bu fikirleri kabul ettirenler tarafından da inşa edilmiştir. Sokrates'e göre ise retorik, siyasetin bir bölümünün benzeridir, sanatla bir ilgisi yoktur, keskin görüş, yiğitlik, insanlarla konuşabilmek için üstün yetenek isteyen bir iştir (1999: 27-47).

Burke için dil, insanların dünyayı inceleme ve anlama tarzını, retorik ise insanların birbirleriyle iletişim kurma tarzını anlatır. Burke'nin retoriği, klasik retorikten bütünüyle ayrılır. Yunan ve Latin geleneğini izleyen klasik retorik iknâya yoğunlaşırken, Burke'nin yeni retoriği özdeşleşmeye, başka bir ifadeyle nitelikleri bakımından eşit ve denk olmaya odaklanır, özdeşleşme olmadan iknânın sağlanamayacağını ileri sürer (1969: 123).

Booth'un (2012) "bir romanın keyfî bir konu seçkisinin ve konunun problemlerinin seçiminde, biçimsel güzellikler ya da ironik giriftlikler yerine etkili retorik ifadeler belirlenmelidir" ifadesinden anlaşıldığı üzere, Booth'a göre retorik, kurmaca metinlerdeki sanatsal söylemlerdir.

Meyer (2009) iletişimin tek aracının dil olmadığını, dilin sanatı kullanımının da bir iletişim aracı olduğunu belirtir ve bu görüşe bağlı olarak edebî retorik ve gündelik yaşam retoriği ifadelerini kullanır, ikisinin arasındaki en büyük farkın karşılıklı konuşma bağlamı olduğunu belirtir. Meyer'e göre, retorik sanatının kullanıldığı metinlerde ya da söylemlerde, stil, etki ve ikna etme öne çıkarken içerik ve anlam geri planda kalır. Fusillo ise retorikle edebiyat, skolastik* ve estetik arasındaki bağ üzerinde durur (2009: 31).

Türkçede retorik yerine eskiden edebiyat anlamında kullanılan, bugün edebiyatın bir kolu olan ve "Meram, en güzel, en etkileyici bir biçimde nasıl ifade edilir?" sorusuna cevap arayan "belâgat" terimi kullanılmıştır (Karataş, 2001). Belâgat hem düzgün hem de yerinde söz söylemek ve bu usulü öğreten bilimdir (Tahir-ül Mevlevî, 1994). Belâgat terimi için İngilizcede "eloquence", Fransızcada "éloquence", Almancada "beredsamkeit", Yunancada "evgolattía" terimleri kullanılır. Retoriğe yakın anlamlı olarak kullanılan bu terimler, belâgat ile retorik arasında ayırt edici bir fark olduğunun işaretidir.

\footnotetext{
*Skolastik, [Alm.scholastik] [Fr.scolastique] [ing.scholostic] [Lat.scholosticus<schola=okul], inanç ile bilgiyi, kilise öğretisiyle özellikle Aristoteles'in bilimsel dizgesini uyumlu bir biçimde birleştirmeye çalışan orta çağ felsefesi. Ereği, usu dinin doğrularına uygulayarak inanç konularını kavranılır kılmaktır (Akarsu, 1975).
} 
Nietzsche, belâgat kurallarıyla retorik figürler arasında fark görmez. "Trop* dilin türemiş, marjinal veya sıra dışı formu değil, kusursuz lengüistik bir paradigmadır" sözüyle, aslında dilin bir retorik olduğunu belirtir (Blair, 1983: 95). Bu görüşler değerlendirildiğinde, belâgatte estetik, retorikte estetiğe bağlı iknâ etmenin ön plana çıktığı anlaşılır.

\section{RETORİK SORU}

Retorik soru, soru cümlesi olup da soru sormayan, duygu ve düşünceleri daha açık, daha güçlü, daha etkili bir şekilde ifade etmek, muhatabı heyecanlandırmak, ikna etmek gibi amaçlarla kullanılan cümlelerdir. Daha çok sözlü dilde görülen retorik soru, yapı olarak soru olsa da semantik olarak cevabı bilinen veya beklenmeyen sorudur. Soruyu yönelten aslında karşı taraftan almak istediği cevabı onu etkileyerek, ikna ederek almaya çalışır (Rüzgar ve Akdemir, 2017: 260). Asıl maksadı cevap almak olmayan, gerçek anlamın ve bilgi edinmenin ötesindeki bu cümlelerle gerçek ya da hayali muhatabın bildiğinin var sayıldığı bir konuyla ilgili sorular sorulur. Soruyu soran kişi muhatabının kendisine vereceği cevabı değil, kendi kafasında soruya yüklediği anlamı ön planda tutar. Gerçek anlamda ve birincil işlevde (bilgi edinme) kullanılmaması, soru cümlesini sözde soru cümlesi yapan başlıca özelliktir (Tarcan, 2010: 31). Baştürk sözde soru cümlelerini önceden bilinen bir dizi duyguyu veya düşünceyi dile getiren dolaylı anlatım biçimi olarak ifade eder (2001: 409).

Retorik soru cümlelerinin anlamlarına göre tasnifinde farklı görüşler mevcuttur. Kimi araştırmacılar günlük yaşamda cevap verilmeyen her tür soruyu retorik soru olarak ele alırken kimileri de sanat ve edebiyat ağırlığı olan soru cümleleri kapsamında incelemişlerdir. Bazı araştırmacılar ise retorik soruyu sözde (gerçek olmayan) soruların bir çeşidi olarak kabul eder. Altun (2009) şeklen soru cümlesi olup içerdiği önerme gereği bildirim cümlesi olan retorik soru cümlelerini "Cevap Beklenmeyen Sorular" başlığı altında inceler ve bu soruların üç türünden söz eder: İzin isteme veya rica etme amacıyla kullanılan pratik soru cümleleri; şaşkınlık, öfke, inanamama gibi duyguları güçlendirme ifadesi taşıyan vurgu cümleleri; soru soranın muhataba kendini onaylatmak, söylediğinin tartışılmaz

\footnotetext{
*Trop (Yunanca, değiştirmek anlamına gelen tropein), retorik figürlerin bir kategorisi olup kelimenin genel anlamını değiştiren söz sanatları olarak tanımlanmaktadır (Kireçci, 2009: 131).
} 
olduğunu ifade etmek amacıyla, bir üslup aracı olarak faydalandığı retorik soru cümleleri.

Wilson-Sperber (1988) cevap beklenmeyen soruları işlevleri açısından şöyle sınıflandırmıştır: a) Konuşma sanatıyla ilgili sorular (rhetorical questions), b) Sınav soruları (exam questions), c) Tahmin soruları (guess questions), c) Şaşma soruları (suprise questions), d) Açıklama soruları (expository questions), e) Kendine yönelik sorular (self-adressed questions), f) Spekülatif sorular (speculative questions).

Dizdaroğlu (1976) soru cümlelerinin soru sorma dışında, cümleye kattığı onaylatma, reddetme, yalanlama, olasılık, beğenme, övme, yeğleme, yüceltme, şaşma, bilmezlikten gelme, bilinmezlik, rica, özür dileme, buyruk, yakınma, başa kakma, üzüntü, acınma, güçsüzlük, yetersizlik, küçümseme, azımsama, önemsemezlik, alay, kendini küçük görme, kızma, azarlama, korkutma, meydan okuma, kınama, suçlama; yargıyı sınırlama; yargıyı genişletme, aşırılık; kesinlik; söze duyusallık kazandırma, özlem, gereksizlik gibi detaylı anlam özellikleri üzerinde durur.

Tarcan (2010) bilgi edinme amacıyla sorulan ve karşılığında cevap beklenen cümlelere "gerçek soru cümleleri", gerçek olmayan, cevabı karşıdan beklenmeyen soru cümlelerine de "sözde soru cümleleri" adını verir. Gerçek olmayan (sözde) soruları, sözbilimsel (retorik), söylevsel, içeriği yönlendiren, selamlaşma ritüelleri, yansıma sorular olarak gruplandırır ve sözde soru ile en çok özdeşleşen sorunun retorik soru olduğunu belirtir.

Bilgegil (1989) retorik soru için "istifham" terimini kullanır ve bunları cevaplı istifhamlar ve cevabı pekiştiren istifhamlar biçiminde gruplandırır.

Üstünova (2004) soru-cevap cümlelerini birer mini mikro metin niteliğinde olduğunu belirtir ve soru cümlelerini, cevap isteyen soru cümleleri ve cevap istemeyen soru cümleleri olmak üzere iki gruba ayırır. Cevap istemeyen soru cümlelerini, istenmediği hâlde cevabı olan soru cümleleri ve cevabı olmayan soru cümleleri olarak gruplandırır.

Schaffer (2005) gerçek bir bilgi veya eylemi ortaya çıkaran soruya cevap olarak sunulan bir retorik sorudan söz eder. Bu cümleler, "Neden olmasın?" gibi eksiltili sorular ve sorulara cevap 
vermek için kullanılanlardan farklı olarak, "Sormana gerek var mı?" örneğindeki gibi, konuşma zinciri boyunca cevabı açık olan sorulardır.

Retorik sorular, gülmecelerde de başvurulan yollardan biridir. Şensoy retorik soruya bağlı gülmece üslubunu şöyle sınıflandırılır:

a) Sorulan soruya dilin olağan kullanımında, onaylama dışında, cevap verilmemesi gereken ancak cevap verilince komik bir durumun çıkarılacağı sorulardan oluşur. Örnek: "Taze elma var mı?" sorusuna olumsuz cevap vermek komik olacağı için sorunun sorulması ve cevaplanması da gülmece aracı olur.

b) Gülmeceye neden olan sorunun yanıtının soruyu soran tarafından verilmesidir. Birisine yardım amacıyla para verdiğimizde o kişinin bu durumdan rahatsı olarak sinirlendiğini ve "Dilenci miyim ben?" şeklinde soru sorması örnek gösterilebilir.

c) Bir ifadeye karşılık doğrudan retorik bir soruyla karşı bildirimde bulunulmasıdır. Örnek olarak, bakkala gidip çikolata istediğinizde ve bakkaldaki çalışanın çikolataların yerini bir türlü bulamayıp "Nereye koydum bu çikolataları, hepsini yemedim ya?" şeklinde sorması gülmeceli retorik sorudur (akt. Rüzgar ve Akdemir, 2017: 262).

Esas olarak, retorik sorulara cevap beklenmediği için bu sorulara verilecek olan her tür cevap gülmece ya da ironiye dönüşebilir.

\section{YÖNTEM}

$\mathrm{Bu}$ çalışmada Köktürkçe, Uygur Türkçesi, Karahanlı Türkçesinden başlanarak Eski Anadolu Türkçesi, Osmanlı Türkçesi, Türkiye Türkçesi dönemlerinde yazılmış bazı eserlerdeki retorik soru cümleleri tespit edilmiş ve anlamlarına göre sınıflandırılmıştır. Makale çerçevesini aşmamak için eser sayısı sınırlandırılmış, her döneme ait en az bir eser taranmıştır. Taranan bütün retorik soru cümleleri makaleye dahil edilememiş, diğerlerine göre ayırıcı nitelik taşıyan örnekler tercih edilmiştir. Derlenen bu cümleler metin içi ve metin dışı ögeler esas alınarak incelenmiş ve anlamlarına göre sınıflandırımıştır.

Metin içi incelemelerde retorik soru cümlelerinde yer alan sıfatlar; zarflar, edatlar cümlenin işaret ettiği zaman ve kip türü üzerinde durulmuştur. Metin dışı incelemelerde, edim bilimi-sözcelem kuramlarından yararlanılmış, retorik soru cümlesinin kullanıldığı bağlam çerçevesinde sözcelem anı ve durumu ile dil dışı etkenler göz 
önünde bulundurulmuştur. Metin içi ögeler, gerçek soru cümlesini sözde soru cümlesine dönüştüren ögelerdendir; ancak esas olarak retorik soru cümlesi ile gerçek soru cümlesi arasındaki fark, edim bilimseldir.

Dili bağımsız, yapısal bir nesne olarak gören yapısal dil bilimden farklı olarak edim bilimi, sözceleri bir sözcelem durumu içinde, gerçek bir dilsel iletişimde; sözcelerin anlamını kişi, zaman ve uzam göstericileriyle belirlemektedir (Kıran ve Kıran, 2000: 265). Aristoteles'e kadar dayanan Frege-Russel-Wittgenstein'in "Dilin ana işlevi olguları betimlemektir" görüşüne itiraz eden Austin, ortada biri konuşan öteki dinleyen olmak üzere en az iki kişinin bulunduğu ya da bulunduğunun varsayıldığı, konuşan kişinin ne söylüyorsa onu anlatmaya çalıştığı ciddi ve olağan bir iletişim ortamını dikkate alarak konuşan kişinin dilsel davranışını çözümler (Searle, 2000: 13).

Bir yazar için sözceleme, yazma edimidir. Bu edimi oluşturan ögeler üretilen sözcede ya da metinde kendilerini gösterirler. Bir metinde önemli olan, kim kiminle, nerede, ne zaman ve nasıl sorularına yanıt vermesidir. Yazar ürettiği metne açıkça müdahale eder mi? Bu müdahaleyi bir anlatıcı aracılığıyla mı gerçekleştirir? Neden bir anlatıyı hangi kişi adılıyla aktarır? Bir sahneyi, bir yeri, bir kişiyi hangi bakış açısıyla betimler? Yarattığı kiş̧ilere göre kendisini nereye koyar, bir başka deyişle hangi bakış açısını seçer? Okurun bakış açısına nasıl ulaşır? Okurla arasına bir mesafe koyar mı? Özdeşleşmeyi kolaylaştırmak için kahramanın yanında yer alır mı? Sözceleme olgusu bu soruların tümünü yanıtlamasa da metinlere nesnel bir yaklaşımı sağlayarak metin konusunda yeni sorular sorulmasını, yanıtlar alınmasını sağlar (Kıran, 1999: 99).

\section{TÜRK DİLİNDE RETORİK SORU}

Çalışmanın bu bölümünde Köktürkçe, Uygur, Karahanlı, Eski Anadolu, Osmanlı ve Türkiye Türkçesi dönemine ait bazı metinlerde, retorik soru yapıları, metin içi ve metin dışı ögelere göre incelenmiştir. Örnek cümleler, hitabet, dini/siyasi nasihatname, destan, manzum metin*, öykü türündeki yazılı metinlerden alınmıştır. Örnek cümlelerin alındığı metinlerin yazarının/şairinin bakış açısı, metinde konuşan kişi/kişiler, hitap edilen kişi/kişiler belirlenmiştir. Örnek olarak, Tunyukuk Anıtının metin yazarının Bilge Tunyukuk

*Osmanlı Türkçesi dönemindeki divan şiirleri daha geniş bir çalışmayı gerektirdiği için inceleme dışında bırakılmıştır. 
olduğu kesin olarak bilinmekle birlikte, Köl Tigin ve Bilge Kağan bengü taşlarının yazarı/yazarları konusunda farklı görüşler vardır. Araştırmacılar, anıtlarda konuşan kişinin Bilge Kağan olduğu konusunda hem fikirdirler; Bilge Kağan ve Oğul Bilge (Tenri) Kağan tarafından hazırlanan metinlerin, Yollug Tigin tarafından not edilmiş, taşlara oyularak yazılmış olduğu tahmin edilmektedir (Ercilasun, 2016: 400). Hitabetin üslubunun hakim olduğu bu metinlerde konuşucunun muhatabı Türk milletidir. Anıtlar, hükümdar tarafından hitabet tarzında söylenmiş öğüt verici edebi tarih metinleridir. Gönderici-alıcı ilişkisi bakımından üst makamın alt makama seslenişi söz konusudur. Bu bağlamda, metindeki retorik sorular yaygın olarak cevabı kesin olan, cevap beklenmeyen sorulardır ve sorgulama kipi hakim ögedir. Sorgulamalar, anlamsal olarak etkileşime duygusal değer katan anlaşma/anlaşmazlık üzerine kurulu sorulardır.

Dünya ve öteki dünyada erdemli yaşamanın yollarına dair nasihatlerin yer aldığı Kutadgu Bilig'de ve dini içerikli Uygur Türkçesi metinlerinde, sıfır odaklayım bakış açısı vardır. Sıfır odaklayımda, anlatıc kendinden "ben" diye söz etmez, hep 3. teklik kişi zamiri olarak kalır, her zaman ve her yerdedir, tüm güçlere sahiptir, okur ile paylaştığı anlatının tüm verilerine egemendir. Muhatap ise sen/siz 2. şahıs zamirleridir. Bu metinde retorik sorular, daha çok emir, gereklilik, yasak anlamlarındadır, bu anlamlar eklenti ve yönlendirici sorular aracılığı ile aktarılmıştır. Yüklem, emir kipi, gelecek zaman ve yaygın olarak, geniş zaman ile çekimlenir. Geniş zaman burada, genel geçer kuralların bildirimini sağlayan bilgi kipliği durumundadır.

Destan türü metinlerde ise hayal kırıklığı, çaresizlik soruları ve eklenti sorular daha fazladır. Lirik manzum metinlerde öznel sorgulama türü ve tecâhül-i ârif sanatı olarak kullanımının daha yaygın olduğu görülür. Öykü türünde ihtimal, şüphe, sorgulama kipindeki soruların kullanım alanı geniştir. Esas olarak retorik sorular her tür metinde kullanılmıştır; ancak bu soruların ağırlıklı kullanım alanları metnin türüne göre değişmektedir.

\section{1. İhtimal, Şüphe, Sorgulama Bildiren Retorik Soru}

Türkçede sorgulama kipi soru eki ve soru kelimeleri ile kurulur. Soru eki, cümlede vurgulanan ögeye eklenir, soru kelimesi sorgulanan ögeye yöneliktir. Cümle içinde, sorgulanan konuya zıt niteleyicilere yer verilir. Günümüz Türkçesinden örnek verecek olursak, "Bu kadar tahsil görmüş biri nasıl böyle davranır?" Bu 
cümlelerde, zıt niteleyicilerin betimlendiği bölümde görünüş olarak bitimli fiiller kullanılır. Kimi cümlelerde betimleme yerine şart cümlesi kullanımlarına da rastlanır:

(1) Türk amtı bodun begler, bödke, körügme beglergü yanıltaçı siz? (KT G-11)

"Şimdiki Türk milleti ve beyleri! Şimdi (bengü taşlara) bakan (görmüş olan) beyler (olarak) mı yanılacaksınız?"

(2) Üze tenri basmasar, asra yir telinmeser, Türk bodun, ilinin törünin kim artatı udaçı erti? (KT G-22)

"Üstte gök basmasa, altta yer delinmese Türk milleti, (senin) devletini, yasalarını kim bozabilirdi (bozabilecekti)?"

(3) Sözüm oğluma sözledim men tona; Ogul minde altın mana ne tene? $(K B, 186)$

"Ey yiğit, ben bu sözü oğlum için söyledim oğul benden aşağı derecededir ve bana nasıl denk olur?"

Konuşucunun 1. teklik şahsa gönderim yaptığı retorik sorular, konuşan öznenin kişisel yargısını geliştirmek, açımlamak ve/veya açıklamak üzere öznenin kendisini sorguladığı soru türleridir. Günümüz Türkçesinde "Bu hatayı nasıl yaparım?", "Bu soruları nasıl cevaplayamam?" gibi kullanımları örnek verebiliriz.

(4) Kaganlıg bodun ertim, kağanım kanı? Ne kaganka işig küçüg birür men? (BK, D- 9)

"Kağanlı millet idim, kağanım nerede? Hangi kağana işi gücü veriyorum?"

(5) Ben böyle dağılarak mı öleceğim? (YA, 111)

Sorgulama işlevinde, soru eki ve soru kelimelerinden sonra "acaba" anlamında "erki, erinç" edatı, "ki" bağlacı ve "mı ol-", "aceb /acaba", mı aceb/acep", "-dı ola" gibi kalıplar kullanılır. Çağatay (1964), Uygur Türkçesinde "mı eki" ve "soru zamiri + erki" yapılarının soru ifadesini teyit etme işleviyle kullanıldığını, Arapçadaki "acaba" ile verilen cümlelerin anlam özelliğini taşıdığını ve bu yapıların Divanı Lugat-it Türk'te ve Rabguzi'nin Kısas-ı Enbiya'sında geçtiğini belirtir.

$\mathrm{Bu}$ cümleler sözcelem bakımında anlaşmazlık soruları grubundadır. Fiil zamanının geniş zaman ve gelecek zaman olması intimal ve şüphe anlamını güçlendirir. Geniş zaman çekiminde, 
konuşucu odaklı bir eylem veya durumdan söz edilir. Konuşucu, eylemin veya durumun gerçekleşip gerçekleşemeyeceği konusunda net bilgi aktarmaz, bu belirsizlik yer yer sitem anlamını da kapsar:

(6) Belde turgan biş-on oğlan begim kayda ter mü erki? Bezeklikte kızlar kırkın berter mü köngülin erki? (ETŞ, 29-5)

"Belde duran elli yiğit, Beyim nerede? Der mi acaba? Haremdeki kızlar, cariyeler, kalplerini paralar mı acaba?"

(7) Kanda erinç kanı kı? (DLT, 22) "O şimdi nerededir ki?"

(8) Ol kelir mü erki? (DLT, 65) "O acaba gelir mi?"

(9) Görüp bunları hayran kaldıdı; Bular atama aceb neden kaldıdı? (SN, 227-505)

(10) Aceb bu benüm cânum âzâd ola mı yâ Rab? (YD, 15-1)

(11) Kıran yirde tikilmiş otahlarun; O zalım yıkdurdı ola kardaş? (DK, 210, 222-13)

(12) Kişi koynında yatan halalına sırrın dimez mi olur? (DK, 219, 242-11)

(13) Veremden öldüğünü siz söylüyorsunuz, bir intihar niçin olmasın ki? (YA, 130)

\subsection{Emir, Gereklilik ve Yasak Bildiren Retorik Soru}

Emir, gereklilik, yasak bildirimi, retorik soru ile daha etkili bir biçimde ifade edilir. Bu ifadelerde betimlenen olumsuz durum ve olaylar geçmiş zamanda vuku bulmuştur ve bunların yapılmaması ya da olmaması gerektiği vurgulanmıştır. Bu ifadelerde vurgu, soru eki alan kelimede ve soru kelimesi üzerindedir. Bazı pekiştirilmiş ifadelerde kınama anlamı da vardır:

(14) Körüp neçük kaçmadın?; Yamar suwın keçmedin, tavarınnı saçmadın? (DLT, 38)

"Beni gördüğün zaman niye Yamar suyunu geçip kaçmadın? Malını niçin fırlatıp başını kurtarmadın?"

(15) Neçük antag çulbu sab agzınızta öner? (İKP, A Kalıntısı-14)

"Nasıl böyle hakaret edici bir söz ağzınızdan çıkar?"

(16) Neke tezer biz? Üküştiyin ne ke korkur biz? Az tiyin ne basınalım? (Tunyukuk, 2. Taş-38) 
"Niye kaçıyoruz? Çoklar diye niye korkuyoruz? Azız diye niçin yenilelim?"

(17) Topraga düşmiş tenleri Hakk'a ulaşmış cânları; Görmez misin sen bunları? Nevbet bize gelmiş yatur (YD, 74/4)

(18) Nelük anar biliştim? Kuçşup takı kavuştum? "Onunla niçin tanıştım; kucaklaştım... (DLT, 428)

(19) Negü teg açayın kişike sözüm? (KB, 630) "Nasıl oldu da başkasına sırrımı hemen açıverdim?"

(20) Kişi neyledügin nite bilmez ol? (SN, 198-50)

(21) Bu işke ne ögünç kerek? (DLT, 67) "Bu işin övünülecek nesi var?"

(22) Ne diyorsun oğlum? Sen benim Türk olduğumu unuttun galiba... (TKK, 6)

(23) Rahat duramıyor musunuz? (OKD, 155)

\subsection{Kalıp Sözlerde Retorik Soru}

İletişimde, belirli şartlar altında ve belirli bir durumda, kalıplaşmış sorulara başvurulur. Bu tip sorulara cevabın, genellikle sorunun gerçek anlamı dikkate alınarak sorunun içeriğinin onaylanması biçiminde olması beklenir. Oysa soran kişinin amacı farklıdır (Serindağ, 2013: 273). "Ne de güzelmiş!", "Ne kadar harika!", "Ne diyorsun!?" gibi hayret, şaşkınlık, sürpriz bildiren cümlelerde kullanılır. Bu cümleler sözcelem bakımından anlaşma/anlaşmazlık işlevindedir. Ayrıca izin ve rica cümleleri de kalıplaşmış retorik cümledir:

(24) Ançama yarasınçıg otun karımak? "Ne kadar iğrenç ve kabasın, sen ihtiyarlamak?" (M, 12-39)

(25) Kaç kata aydım? "Kaç defa söyledim?" (DLT, 141)

(26) Negü asgı bar bu ökünçüm bu kün? (KB, 1132) "Bugün bu pişmanlığımın ne faydası var; ölüm"

(27) Cevabum virün uş sorarvan size; kişi ne diye ancılayın kıza? (SN, 534-5004)

(28) Bu ne fena bir şeydir? (OKD, 153)

(29) Kim bilir? Artık yarını beklemekten başka çaremiz yok (TKK, 10) 
(30) Biraz istirahat etmez misiniz? (OKD, 207)

\subsection{Hayal Kırıklığı ve Çaresizlik Bildiren Retorik Soru}

"Nerede, hani, ne, negü, neglük, kanı" gibi soru kelimeleri ile oluşturulan retorik sorularda, geçmişteki olumlu durumun, olumsuza dönmesi karşısındaki çaresizlik, hayal kırıklığı ve bıkkınlık ifade eden öznel sorgulamalar vardır:

(31) Kaganlıg bodun ertim, kağanım kanı? (BK, D-9) "Kağanlı millet idim, kağanım nerede?"

(32) Bu ne emgeklig yer ermiş? Neglük togdum men kanı? (İKP, IV-6) "Bu ne çileli yermiş? Ben niye doğdum?"

(33) Otuz yıgmışın yandru aldı elig; Negü kılgay altmış tegürse elig? (KB, 368)

"Otuzun topladığını elli geri aldı, altmış elini değdirirse, ne yapacağım?"

(34) Apa oglanı körse arkış sanı; Örüg turgu bolmaz örügler kanı? (KB, 1386)

"İnsanoğlu, bakarsan, bir kervana benzer, konak yerinde devamlı kalınmaz, menziller nerede?"

(35) Neylersin? Ölüm herkesin başında (OBY, 202)

\subsection{Yönlendirme Bildiren Retorik Soru}

$\mathrm{Bu}$ sorularda, konuşucu, muhatabının cevabını bekler; ancak istediği cevabı almak için yönlendirici ifadeler kullanır. Harrison, kilise grubundaki Kongolu kadınların kendi bakış açılarını tartışmak için ve muhataplarını, kendi bakış açılarını kabul etmeye ikna etmek ve eylemlerini yönlendirmek için retorik sorular kullandıklarını tespit etmiştir. Konuşmacı, kendi bakış açısını benimsetmede başarılı olursa, dinleyici bu bakış açısıyla ilgili sorumlulukları da yerine getirmekle yükümlü olur (2008:121). Türkçede yönlendirici soru kalıplarında soru ekinin ve soru kelimelerinin kullanıldığı görülür. Bu soru kalıplarının yüzey yapıdaki anlamları derin yapıda tersine döner. Yüzey yapıda olumlu cümle derin yapıda olumsuz, yüzey yapıda olumsuz cümle ise derin yapıda olumluya dönüşür. Bu sorular, yargı geliştirici sorgulamaları içerir. İncelediğimiz metinlerde yönlendirici retorik sorunun geniş bir kullanım alanı olduğu görülmüştür: 
(36) Azu bu sabımda igid bar gu? Türk begler, bodun, bunı eşidin (KT G-10)

"Yoksa bu sözlerimde yalan var mı? Türk beyleri, millet, bunları işitin"

(37) Kan kazgansar oglı üçün temez mü? (İKP, VIII-3) "Eğer baba kazanırsa oğlu içindir denmez mi?"

(38) Anı teg savlarnıng açukın bilser; adruk ermez mü biligte? (ETŞ, 106-5)

İnsan öyle sözlerin seçkinini bilirse, bilgide daha üstün olmaz mı?"

(39) Barışmayı becermenin de savaşmak kadar değeri yok mu? (Salih Tuna, 20 Mart 2009, Yeni Şafak)

(40) Ebedi zillete mahkum edemem doğrusu ben; daha bîçâre miyiz yoksa Mecûsîlerden (S, 158)

(41) O dönemde çok yakın olduğumuzu sandığım, ustam bildiğim kişiler sonra hayatımdan hatırasız ya da karanlık hatıralarıyla çıkıp gitmediler mi? (YA, 88)

\subsection{Eklenti Soru Olarak Retorik Soru}

Eklenti sorularda konuşucu, ürettiği iletinin muhataba ulaşıp ulaşmadığını sınar ve iletiye yönelik ısrarını vurgular. Konuşucu, muhataptan onaylama beklemekle birlikte söylemin içeriği ile ilgili bir anlaşma zemini de hazırlar. Bu sorular karşılıklı sözcelemede, anlaşma veya anlaşmazlığa dayalı sorulardır:

(42) Birdem kirtgünüp tudgıl yemüsizin me manga? (ETŞ, 12022)

"Tam bir iman ile ona sarıl, olur mu? Benden şüphe etme"

(43) Amrak ögüküm menin elte kazgançım sizin ermez mü? (İKP, XVI-3)

"Sevgili yavrucuğum, benim devlet gelirlerim sizin değil mi?

(44) Ağ elleri ardına bağlı diyeyin mi? Ağ boynında kıl urgan takılu diyeyin mi? (DK, 171, 146-8) 


\subsection{Bilmezlikten Gelme (Tecâhül-i Ârif) Sanatında Retorik Soru}

Bazı belâgat kitaplarında retorik sorular, tecâhül-i ârif sanatı ile birlikte ele alınmıştır. Tecâhül-i ârif sanatı, muhatabın dikkatini çekmek, zihninde sorular oluşturmak amacıyla kullanılır. Bu cümlelerde sorgulama anlamının yanı sıra ağıt, methiye amacıyla konuşucuyu derinden etkilemiş olan hatıralar da yâd edilir. Sıralı cümleler halinde aktarılan bu ifadelerde adeta hayata dair yaşananlar tek tek sıralanır ve betimlenir:

(45) Aklar bulıt örlep kükirep; Alkuka mu ḳaryagurur? Ak bir saçlıg karı anam; Açuyı mu yaşların aḳıdur? (ETŞ, 28-1) "Ak bulutlar yükselip gürleyerek her tarafa kar mı yağdırır? Ak saçlı o ihtiyar annem acılar içinde mi göz yaşlarını akıtır?"

(46) Bu yoklık yolına bugün bize yoldaş olan kimdür? İlümüze gönilelüm sorun kardaş olan kimdür? (YD, 30)

(47) Kalkubanı yiründen turmadun mı? Yilisi kara kazılıkatun binmedin mi? (DK, 189)

(48) Benim mi Allahım bu çizgili yüz? Ya gözler altındaki mor halkalar? (OBY, 202)

\section{SONUÇ VE ÖNERİLER}

Sonuç olarak, incelemeye esas alınan dönemlere ait eserlerde retorik soru cümlelerinin çeşitli anlam alanlarında kullanıldığı görülmüştür. Esas itibarıyla her soru cümlesinin retorik soruya dönüşebilme özelliği vardır. Retorik soru ile gerçek soru arasındaki fark edim bilimseldir.

Anlatım biçimi, metnin farz edilen muhatabı, metnin üretilme amacı ve metnin türü retorik sorunun anlamını belirlemede etken olan önemli ögelerdendir. Esas olarak retorik sorular her tür metinde kullanılmıştır; ancak bu soruların ağırlıklı kullanım alanları, metnin türüne göre değişmiştir. Hitabet türünde olan Köktürk Yazıtlarında, retorik sorular yaygın olarak cevabı kesin olan, cevap beklenmeyen sorulardır ve sorgulama kipi hakim ögedir. Sorgulamalar, anlamsal olarak etkileşime duygusal değer katan anlaşma/anlaşmazlık üzerine kurulu sorulardır. Dünya ve öteki dünyada erdemli yaşamanın yollarına dair nasihatlerin yer aldığı dini konularda yazılmış olan Uygur Türkçesi metinlerinde ve Kutadgu Bilig'de, emir, gereklilik, yasaklar yönlendirici sorular aracılığı ile aktarılmıştır. Dede Korkut 
Hikayelerinde destansı bir söyleyiş vardır ve hayal kırıklığı, çaresizlik soruları ve eklenti sorular daha fazladır. Lirik manzum metinlerde öznel sorgulama türü ve tecâhül-i ârif sanatı olarak kullanımının daha yaygın olduğu görülür. İleri'nin (2012) Yağmur Akşamları eserine bağlı olarak, öykülerde ihtimal, şüphe, sorgulama kipindeki soruların kullanım alanının geniş olduğunu söylemek mümkündür.

Esas olarak bu makale, retorik soruların bütün anlam alanlarını ortaya koyacak kapsamda değildir. Sadece, Türkçe dil bilgisi incelemelerinde bu tür soruların anlam olarak sınıflandırılmasının ve bu sınıflandırmada esas alınacak yöntemlerin önemi vurgulanmaya çalışılmıştır. Türk Dilinde retorik soru cümleleri üzerinde daha geniş izahat ve sınıflandırmalar için döneme ve esere bağlı monografik çalışmalara ihtiyaç vardır.

\section{KISALTMALAR}

BK: Bilge Kağan Abidesi

D: Doğu Yüzü

DLT: Divanı Lugâti't-Türk

DK: Dede Korkut

ETŞ: Eski Türk Şiiri

G: Güney Yüzü

İKP: İyi ve Kötü Prens Öyküsü

KB: Kutadgu Bilig

KT: Kül Tigin Abidesi

M: Uygurca Metinler II Maytrısimit

OBY: Otuz Beş Yaş

OKD: Osmanlıca Konuşma Dili

S: Safahat

SN: Süheyl ü Nevbahâr

TKK: Türklerin Kayıp Kitabı

YA: Yağmur Akşamları

YD: Yûnus Divânı

\section{KAYNAKÇA}

Acarlar, K. (1970). Mi Ekinin Türlü Kullanılışları. Türk Dili 22, 358363.

Ağakay, M. A. (1952). Soru Cümleleri Üzerine. Türk Dili 1, 683-684.

Akarsu, B. (1975). Felsefe Terimleri Sözlüğ̈̈. Ankara: Türk Dil Kurumu Yayınları. 
Altun, H. O. (2009). Türkçede Soru. (Yayımlanmamış Doktora Tezi). Marmara Üniversitesi Türkiyat Araştırmaları Enstitüsü, Türk Dili ve Edebiyatı Anabilim Dalı, Türk Dili Bilim Dalı, İstanbul.

Aristotales. (2019). Retorik. (Çev.). A. Çokona. İstanbul: Türkiye İş Bankası Kültür Yayınları.

Ateş, A. E. (2016). İstifhâm Üslûbunun Mecâzi Kullanımları ve Meallere Yansıması. Çanakkale Onsekiz Mart Üniversitesi İlahiyat Fakültesi Dergisi 8, 123-141.

Austin, J. L. (2009). Söylemek ve Yapmak. (Çev.). R. L. Aysever. İstanbul: Metis Yayınları.

Baştürk, M. (2001). Sözcelem Dilbilimi ve Türkçe'de Soru. Yüzüncü Yıl Üniversitesi Dilbilim ve Hermenötik Sempozyumu. Erzurum: Bakanlar Matbaası, 399-412.

Baytok, A. (2006). Kırgız Türkçesinde Evet/Hayır Soruları. Modern Türklük Araştırmaları Dergisi 3(3), 78-99.

Bilgegil, M. K. (1989). Edebiyat Bilgi ve Teorileri (Belâgât). İstanbul: Enderun Kitabevi.

Booth, W. C. (2012). Kurmacanın Retoriği. İstanbul: Metis Yayınları.

Burke, K. (1969). A Rhetoric of Motives. United States of American Library of Congress Catalog Card Number: 69-16742

Coşkun, A. (2014). İbn Sînâ Felsefesinde Retorik. İstanbul: Litera Yayıncilık.

Çağatay, S. (1964). Türkçede ki<erki. Türk Dili Araştırmaları Yıllığı Belleten 11, 245-250.

Çebi, M. S. (2008). Sembolik/Retoriksel Bir Eylem Olarak Dil'in Anlam İnşasındaki Aracılık İşlevi. İletişim 5(2), 183-198.

Çetin, E. (2008). On Üçüncü Yüzyıl Öncesi Türkçesinde Soru. (Yayımlanmamış Doktora Tezi). Çukurova Üniversitesi Sosyal Bilimler Enstitüsü Türk Dili ve Edebiyatı Bilim Dalı, Adana.

Dizdaroğlu, H. (1976). Tümce Bilgisi. Ankara: Türk Dil Kurumu Yayınları.

Doğan, G. (1997). Buyurmayan Buyrum Tümceleri. VIII. Uluslararası Tür Dilbilimi Konferansı Bildirileri. 7-9 Ağustos 1996, Ankara, 249256.

Duman, M. A. (2015). Platon'un Retorik Anlayışı. İstanbul: Litera Yayıncilık. 
Dürüşken, Ç. (2001). Roma'da Rhetorica Eğitimi. İstanbul: Arkeoloji ve Sanat Yayınları.

Ergin, M. (1985). Türk Dil Bilgisi. İstanbul: Bayrak Yayınları.

Fusillo, M. (2012). Edebiyatta Estetik. (Çev.). F. Demir. Ankara: Dost Kitabevi Yayınları.

Helvacı, S. (2013). Soru Cümlelerinin Edimbilimsel İşlevleri. (Yayımlanmamış Yüksek Lisans Tezi). Gazi Üniversitesi Sosyal Bilimler Enstitüsü Türk Dili ve Edebiyatı Anabilim Dalı Türk Dili Bilim Dalı, Ankara.

Hirik, S. (2019). Dede Korkut Hikâyeleri'nde Söz Edim Yapıları. Manas Sosyal Araştırmalar Dergisi 8 (Ek Sayı 1), 751-768

Karataş, T. (2001). Ansiklopedik Edebiyat Terimleri Sözlüğü. İstanbul: Yedi Gece Kitapları.

Karttunen, L. (1977). Syntax and Semanics Questions. Linguistics and Philosophy 1(1), 3-44.

Keçeli, T. (2009). Rhetorical Yes/No Questions in Turkish. (Yayımlanmamış Yüksek Lisans Tezi). Boğaziçi Üniversitesi Sosyal Bilimler Enstitüsü, İstanbul.

Kıran, Z. (1999). Sözceleme ve Göstergebilim. Dilbilim Araştırmaları, 93-99.

Kıran Z. \& Kıran A. E. (2013). Dilbilime Giriş. Ankara: Seçkin Yayıncilık.

Kireçci, A. N. (2009). Estetik Ürünler ve Görsel Retorik Kuramları Açısından Dergi Reklamlarının Değerlendirilmesi. (Yayımlanmamış Yüksek Lisans Tezi). Marmara Üniversitesi Sosyal Bilimler Enstitüsü Halkla İlişkiler Anabilim Dalı Reklamcılık ve Tanıtım Bilim Dalı, İstanbul.

Kocaman, A. (1996). Edimbilim Üzerine. Dilbilim Araştırmaları 7(185), 11-37.

Korkmaz, Z. (1992). Gramer Terimleri Sözlüğü. Ankara: Türk Dil Kurumu Yayınları.

Meyer, M. (2009). Retorik. (Çev.). İ. Yerguz. Ankara: Dost Kitabevi Yayınları.

Nar, K. (1995). Soru Ekiyle Kurulmuş Soru Cümlelerinin Anlambilimsel Yönden İncelenmesi. (Yayımlanmamış Yüksek Lisans Tezi). Çukurova Üniversitesi Sosyal Bilimler Enstitüsü, Adana. 
Nietzsche, F. \& Blair, C. (1983). Nietzsche's Lecture Notes on Rhetoric: A Translation. Philosophy \& Rhetoric 16(2), 94-129.

Orman, T. F. (2011). Platon'da Retorik Kavramı. Ethos 4(2), 31-46.

Oturakçı, N. (2012). Türkiye Türkçesinde Soru Sözcükleri. (Yayımlanmamış Doktora Tezi). Çukurova Üniversitesi Sosyal Bilimler Enstitüsü Türk Dili ve Edebiyatı Anabilim Dalı, Adana.

Pala, A. İ. (2005). Soru Cümlelerinin Emre Delâleti. Nüsha Şarkiyat Araştırmaları Dergisi 5(17), 67-84.

Platon (1999). Gorgias ya da Retorik Üstüne. (Çev.). M. Rıfat \& S. Rıfat. İstanbul: Kaf Yayıncilık.

Rüzgar, N. \& Akdemir A. (2017). Retorik Söylemin İçerik Kalitesi ve Etkileme Amacına Yönelik Algının Akademisyenler Düzeyinde Araştırılması. Journal of Business Research Turk 9(2), 258-282.

Schaffer, D. (2005). Can Rhetorical Questions Function as Retorts? Is the Pope Catholic?. Journal of Pragmatics 37, 433-460.

Searle, J. R. (2000). Söz Edimleri Bir Dil Felsefesi Denemesi. (Çev.). R. L. Aysever. Ankara: Ayraç Yayınevi.

Serindağ, E. (2013). Kalıplaşmış Retorik Soruların Anlamı Üzerine. Akademik Sosyal Araştırmalar Dergisi 1, 270-275.

Tahir-ül Mevlevî (1994). Edebiyat Lügatı. (Haz.). K. E. Kürkçüoğlu. İstanbul: Enderun Kitabevi.

Tarcan, A. (2010). Bazı Yaygın Dillerde Soru Cümleleri Üzerine SosyoKültürel Bir Yaklaşım. Ankara: Araştırma Yayınları.

Tepebaşlı, F. (2016). Retorik Konuşma Sanatı-Söz Bilimi. Konya: Çizgi Kitabevi.

Tuğluk, İ. H. (2008). Yunus Emre Divanı'ndaki İstifhamların Semantik Açıdan Yorumu. I. Uluslararası Yunus Emre Sempozyumu. 8-10 Ekim 2008, 94-101, Aksaray Üniversitesi, Aksaray.

Türk, V. (2015). Bolgay, Bolga, Ola Üzerine. Türk Kültürü-Türk Kültürü Araştırmaları Dergisi 1, 11-24.

Uzun, N. E. (2004). Dünya Dillerinden Örnekleriyle Dilbilgisinin Temel Kavramları Türkçe Üzerine Tartışmalar. İstanbul: Kebikeç Yayınları.

Uzun, N. E. (2006). Türkçenin Öğretimi İçin Soru Tümcesi Türleri Üzerine Bir Sınıflama Denemesi. Dil Dergisi 131, 15-31.

Üstünova, K. (2004). Soru ve Cevap Cümlelerinin Çözümü. Zeynep Korkmaz Armağanı, Ankara: Türk Dil Kurumu Yayınları, 425-433. 
Vardar, B. \& Güz, N. vd. (1998). Açıklamalı Dilbilim Terimleri Sözlüğü. İstanbul: $A B C$ Kitabevi.

Wilson, D. \& Sperber, D. (1988). Mood and the Analysis of NonDeclarative Sentences. In J. Dancy \& C. Taylor (Eds), Human Agency: Language, Dutyand Value, Stanford: Stanford University Press.

Wilson, D. \& Sperber, D. (2004). "Relevance Theory" Published in L. Horn \& G. Ward (Eds.). Blackwell's Handbook of Pragmatics, 607632.

Yılmaz, A. U., Yılmaz, S. \& Özsöz, B. (2014). Çeviride Dilbilimsel Yaklaşımın Önemi: Sözlü Türkçede Soru Biçimleri ve İngilizce Çevirileri. Zeynel Kıran'a Armağan (Ed.). V. D. Günay \& S. A. Karakul. İstanbul: Papatya Yayıncılık, 263-282.

Yılmaz, S. \& Yılmaz, A. U. (2015). Sözlü İletişimde Öznel İleti İçeren Sözcükleri Okumak ve Yorumlamak. International Journal of Languages' Education and Teaching 3(3), 379-393.

\section{ÍNTERNET KAYNAKLARI}

Paul De Man, (t.y). Erişim Adresi: https://www.aymavisi.org/felsefe/TropRetorigi(nietzsche).html (Paul de Man), Erişim Tarihi: 16.3.2020.

\section{ÖRNEKLERİN ALINDIĞI ESERLER}

Arat, R. R. (1986). Eski Türk Şiiri. Ankara: Türk Tarih Kurumu Yayınları.

Arat, R. R. (1991). Kutadgu Bilig I. Ankara: Türk Dil Kurumu Yayınları. Dilçin, C. (1991). Mesud Bin Ahmed Süheyl ü Nevbahâr. Ankara: Türk Dil Kurumu Yayınları.

Ercilasun, A. B. \& Akkoyunlu, Z. (2014). Kâşgarlı Mahmud Divânu Lugâti't-Türk Giriş-Metin-Çeviri-Notlar-Dizin. Ankara: Türk Dil Kurumu Yayınları.

Ercilasun, A. B. (2016). Türk Kağanlığı ve Türk Bengü Taşları. İstanbul: Dergâh Yayınları.

Ercilasun, A. B. (2017). Türklerin Kayıp Kitabı Ulu Han Ata. Ankara: Akçağ Yayınları.

Ergin, M. (1989). Dede Korkut Kitabı I. Ankara: Türk Dil Kurumu Yayınları.

Ersoy, M. A. (1987). Safahat. İstanbul: Gonca Yayınevi. 
Hamilton, J. R. (2011). İyi ve Kötü Prens Öyküsü. (Çev.). V. Köken. Ankara: Türk Dil Kurumu Yayınları.

İleri, S. (2012). Yağmur Akşamları. İstanbul: Everest Yayınları.

Kartallıoğlu, Y. (2017). Osmanlı Konuşma Dili. İstanbul: Kesit Yayınları.

Tarancı, C. S. (2019). Otuz Beş Yaş Bütün Şiirleri. (Der.). A. Bezirci. İstanbul: Can Yayıncilık.

Tatçı, M. (2011). Yûnus Emre Dîvân Risâletü'n Nushiyye. İstanbul: H Yayınları.

Tekin, Ş. (1976). Uygurca Metinler II Maytrısimit. Ankara: Atatürk Üniversitesi Yayınları. 